\title{
The Potential Role of Apoptosis in Human Disease
}

\author{
Bengt Fadeel Sten Orrenius Boris Zhivotovsky \\ Institute of Environmental Medicine, Division of Toxicology, Karolinska Institutet, \\ Stockholm, Sweden
}

\section{Key Words}

Apoptosis · Caspases · Fas/APO-1/CD95 . Therapeutic intervention

\begin{abstract}
Programmed cell death or apoptosis is an evolutionarily conserved process which is essential for the maintenance of tissue homeostasis. Recent studies have indicated a role for apoptosis in a variety of human diseases. Hence, dysregulation of apoptosis has been implicated in, for instance, systemic and organ-specific autoimmune disease, acquired immune deficiency syndrome, neurodegenerative disorders, atherosclerosis and cancer. This presentation serves as an overview of pathological conditions, which are associated with defective or inadvertent apoptosis, with examples of disorders in which putative apoptosis defects have been elucidated at the molecular level. A critical assessment of apoptosis as a target for therapeutic intervention is also provided.

Copyright $@ 2001$ S. Karger AG, Basel

\begin{tabular}{ll}
\hline KARGER & (1) 1998 S. Karger AG, Basel \\
Fax +4161306 1234 & 1011-7571/00/0093-0151\$17.50/0 \\
$\begin{array}{l}\text { E-Mail karger@karger.ch } \\
\text { www.karger.com }\end{array}$ & $\begin{array}{l}\text { Accessible online at: } \\
\text { www.karger.com/journals/mpp }\end{array}$
\end{tabular}
\end{abstract}

While the role of programmed cell death in embryogenesis had been established earlier $[1,2]$, naturally occurring cell death did not receive widespread recognition until the publication of the seminal paper on apoptosis by Kerr et al. [3]. These authors highlighted the significance of controlled cell deletion and described the morphological features of this phenomenon, which they proposed plays a 'complementary but opposite role to mitosis in the regulation of animal cell populations'. The importance of their study lies not only in the detailed morphological description of apoptosis (a term derived from the Greek word describing the falling off of petals from a flower or leaves from a tree), but also in the recognition of natural cell death as a widespread phenomenon not restricted to embryogenesis. An important corollary is that apoptosis is a genetically regulated process and as such may be amenable to therapeutic intervention.
Prof. Sten Orrenius

Institute of Environmental Medicine, Division of Toxicology Karolinska Institutet, Box 210

S-171 77 Stockholm (Sweden), Tel. +46 87287590 Fax +4683290 41, E-Mail Sten.Orrenius@imm.ki.se 


\section{The Morphology of Cell Death}

Apoptosis occurs in a programmed sequence of morphological events [4]. The cell first undergoes nuclear and cytoplasmic condensation with blebbing of the plasma membrane. Eventually, the cell breaks up into membrane-bound fragments, termed apoptotic bodies, containing structurally intact organelles as well as portions of the nucleus. Subsequently, the apoptotic bodies are recognized, ingested and degraded by neighboring cells. Since apoptosis typically does not induce bystander cell death, it is normally not associated with inflammation. Necrosis, on the other hand, is a mode of cell death characterized by irreversible swelling of the cytoplasm and organelles, including the mitochondria. Eventually there is loss of membrane integrity resulting in cell lysis and release of noxious cellular constituents. Typically, a number of contiguous cells are affected, and exudative inflammation develops in the surrounding tissue. Necrosis occurs when cells are subjected to lethal insults, such as hyperthermia, hypoxia, ischemia, complement attack, metabolic poisons and direct cell trauma [4]. Moreover, under some pathological conditions both types of cell death, i.e. necrosis and apoptosis, may occur. For instance, ischemic damage is frequently characterized by a core of acutely damaged necrotic cells and a penumbra of cells which undergo delayed apoptotic death [5]. The 'decision' of the cell to die by necrosis or apoptosis is thought to depend largely on the severity of the insult.

\section{The Apoptosis Program and Its Regulation}

Research on apoptosis has increased dramatically in recent years, due largely to the realization that apoptosis is an inherently gene-regulated process, whose core components have been conserved through evolution. The strongest evidence for an intrinsic death program comes from genetic studies in the nematode Caenorhabditis elegans [6]. During the postembryonic development of C.elegans, 131 of the 1,090 cells die in every nematode. Loss-of-function mutations in two genes, ced-3 and ced-4, and gain-of-function mutations in a third gene, ced-9 $($ ced $=$ cell death abnormal), were found to prevent all of these 131 naturally occurring deaths. The subsequent isolation and molecular characterization of these nematode 'killer' genes revealed that ced-3, ced-4 and ced-9 all have mammalian counterparts known to be involved in apoptosis. Hence, ced-3 is highly homologous to the human interleukin-1 $\alpha$-converting enzyme (or caspase 1), while ced-9 was shown to be a functional homologue of the human antiapoptotic protein Bcl-2. More recently, apoptotic protease-activating factor 1 has been demonstrated to be a human homologue of ced-4 [7]. Collectively, these findings have underscored the remarkable degree of conservation of the cell death pathway from nematodes to humans and are suggestive of the existence of a core death program in all cells.

A detailed account of the apoptosis signaling pathways employed in mammalian cells is beyond the scope of this presentation and has been subject to excellent reviews elsewhere [8]. However, it is important to note that the cysteine proteases known as caspases, now comprising a family of 14 mammalian members, have emerged as the central executioners of apoptosis activated by a variety of apoptotic stimuli. Moreover, in addition to their role in energy production, mitochondria have been shown to be critically involved in apoptosis signaling in numerous systems by releasing apoptogenic factors, including the recently characterized apoptosis-inducing factor, cytochrome $\mathrm{c}$ and several procaspases [9]. The 
plasma membrane receptor designated Fas (also known as APO-1 or CD95) has emerged as a key regulator of apoptosis within the immune system [10]. Fas-mediated apoptosis proceeds via a caspase-dependent pathway, with mitochondria serving in some cases to amplify the initial death signal. Apoptosis mediated through 'death receptors', such as Fas, or directly via mitochondria is regulated, in turn, by the pro- and antiapoptotic members of the rapidly expanding Bcl-2 family, which includes several human homologues of the recently characterized $C$. elegans death activator egl-1 [6, 11]. Finally, the recognition and engulfment of apoptotic cells by neighboring phagocytes is an important part of the apoptotic process [12]. Indeed, apoptosis can be viewed essentially as a convenient cell clearance mechanism. Numerous candidate receptors and ligands have been identified, which regulate phagocytosis of apoptotic cells in mammalian systems [13]. In addition, genes regulating the clearance of dead cells in C. elegans have also been characterized and have in some cases proven to be homologues of known mammalian genes [6].

\section{Dysregulation of Apoptosis in Human Disease}

In every human being about a hundred thousand cells are produced every second by mitosis, and a similar number of cells die by apoptosis [8]. It is therefore of critical importance that these events be tightly regulated. Consequently, malfunction of the death program intrinsic to every cell may play a role in various diseases, with essentially too little or too much apoptosis leading to proliferative or degenerative diseases, respectively (table 1). In the following sections some illustrative examples of diseases where apoptosis dysregulation has been implicated are highlighted, to- gether with a brief discussion of potential apoptosis-modulating therapeutic strategies now at hand.

\section{Autoimmune Disease}

The activation of $\mathrm{T}$ lymphocytes is known to lead to the concomitant upregulation of Fas and Fas ligand and to the susceptibility of these cells to Fas-mediated killing. Such activation-induced cell death is essentially a mechanism for 'switching off' the immune response, and there is now experimental evidence that accelerated induction of apoptosis in T lymphocytes can limit autoantigen-driven immune responses [14]. These observations thus offer the basis for novel strategies in the treatment of autoimmune disease. The importance of Fas and its corresponding ligand in the homeostatic regulation of immune responses was underscored by the abnormalities observed in mice homozygous for the $\operatorname{lpr}$ (lymphoproliferation) and gld (generalized lymphoproliferative disorder) loci [10]. As a result of mutations in the Fas and Fas ligand gene, respectively, these mice develop autoimmune disease, apparently due to the lack of apoptotic deletion of autoreactive lymphocytes. A syndrome has recently been described in humans which closely resembles the murine phenotype, with progressive lymphoproliferation associated with autoimmunity and large numbers of 'double-negative' $\mathrm{T}$ lymphocytes in the peripheral lymphoid system. Studies of these children, commonly grouped into a single entity designated autoimmune lymphoproliferative syndrome (ALPS), revealed profound defects in lymphocyte apoptosis associated with mutations in Fas $[15,16]$. Subsequently, individuals with a related, though more severe, phenotype were described [17]. This syndrome, termed ALPS type II, is characterized by defective lymphocyte and dendritic cell apoptosis, yet with no molecular abnormalities in Fas or Fas ligand. 
Table 1. Role of apoptosis in human disease

\begin{tabular}{lc}
\hline Diseases associated with increased apoptosis & Diseases associated with decreased apoptosis \\
\hline Neurodegenerative disorders & Cancer \\
Alzheimer's disease & Blastoma \\
Amyotrophic lateral sclerosis & Carcinoma \\
Creutzfeld-Jakob disease & Leukemia \\
Huntington's disease & Lymphoma \\
Parkinson's disease & Malignant glioma \\
Retinitis pigmentosa & Sarcoma \\
Spinal muscular atrophy & Seminoma \\
Hematological disorders & Premalignant disease \\
Aplastic anemia & Ataxia-telangiectasia \\
Fanconi's anemia & Paroxysmal nocturnal hemoglobinuria \\
Hodgkin's disease & Myelodysplastic syndromes \\
Myelodysplastic syndromes & Xeroderma pigmentosum \\
Polycythemia vera & Autoimmune disorders \\
Autoimmune disorders & Autoimmune lymphoproliferative \\
Fulminant hepatitis & syndrome (types I and II) \\
Graft-versus-host disease & Systemic lupus erythematosus \\
Hashimoto's thyroiditis & Metabolic disorders \\
Insulin-dependent diabetes mellitus & Niemann-Pick disease \\
Multiple sclerosis & Osteoporosis \\
Rheumatoid arthritis & Wilson's disease \\
Scleroderma & Viral infection \\
Sjögren's syndrome & Adenoviruses \\
Ischemic injury & Baculoviruses \\
Ischemia and reperfusion & Epstein-Barr virus \\
Myocardial infarction & Herpesviruses \\
Stroke & Poxviruses \\
Bacterial and viral infection & \\
Acquired immune deficiency syndrome & \\
Ebola virus & \\
Chlamydia trachomatis & \\
Helicobacter pylori & \\
Salmonella typhimurium & \\
Shigella flexneri & \\
& \\
\hline & \\
\hline & \\
\hline
\end{tabular}

Instead, these patients displayed mutations in caspase 10 resulting in impaired Fas-mediated apoptosis in lymphocytes as well as defective killing induced by TNF-related apoptosis-inducing ligand in both lymphocytes and dendritic cells. Interestingly, cells obtained from children afflicted with the related, yet fatal immunological disorder termed familial hemophagocytic lymphohistiocytosis displayed an intact Fas-mediated apoptotic response with concomitant activation of caspases [18]. However, mutations were subsequently identified in the gene encoding perforin, an important effector molecule of natural killer and cytotoxic T cells, suggesting that familial hemophagocytic lymphohistiocytosis is caused by defective triggering of apoptosis within the immune system [19].

Organ-specific diseases are characterized by a T-lymphocyte-mediated attack on spe- 
cific cell types, including the $\beta$-cells of the islets of Langerhans in insulin-dependent diabetes mellitus (IDDM), oligodendrocytes in the brain in multiple sclerosis and thyrocytes in Hashimoto's thyroiditis. Recent data have implicated the Fas/Fas ligand system in the destructive phase of these autoimmune disorders [20]. Much of what is known about the pathogenesis of IDDM comes from studies of the nonobese diabetic (NOD) mouse. Itoh et al. [21] showed that NOD mice bearing the lpr mutation were protected from the development of diabetes, and adoptive transfer of splenocytes from diabetic NOD mice to these animals also failed to induce disease, suggesting that the Fas/Fas ligand system plays a key effector role in the pathogenesis of IDDM. Calcium is one of the most versatile and universale signaling molecules in the body and can function as either a trigger or inhibitor of apoptosis [22]. We have previously shown that specific calcium channel blockers prevent apoptosis in pancreatic $\beta$-cells treated with serum from IDDM patients [23]. Similarly, Srinivasan et al. [24] have reported that serum from diabetic patients with neuropathy induces calcium-dependent neuronal apoptosis. Moreover, high glucose concentrations induce apoptosis in $\beta$-cells, which is dependent on intracellular calcium [25]. Collectively, these findings suggest a role for apoptosis in the destruction of insulin-producing $\beta$-cells evidenced in diabetes patients.

\section{Neurodegenerative Disease}

In the vertebrate central nervous system, a large proportion of neurons die before embryonic development is complete. Only those neurons receiving enough neurotrophic support from their target cells will survive, and the rest are believed to be deleted by the process of apoptosis. It has become apparent that excessive or inadvertent apoptosis also occurs in various neuropathological conditions [26].
Particular interest has been devoted to the role of caspase in the pathogenesis of chronic neurodegenerative conditions such as Alzheimer's disease and Huntington's disease, although a role for caspases in acute traumatic [27] and ischemic neuronal damage (discussed below) has also been suggested. The importance of caspases in neuronal apoptosis has been further underscored by the restricted phenotype of caspase 3 and caspase 9 knockout animals, which displayed profound abnormalities in neural tissues despite a normal development of other organs including the lung, liver and thymus [28]. Of interest, the Huntington's disease gene product, huntingtin, was shown to be a substrate for caspase 3 [29]. Hence, caspase activation may play a role in this progressive neurodegenerative condition, although it is presently unknown in which way the fragments liberated by caspase cleavage are linked to the selective loss of neuronal populations. However, if a relationship between neurotoxicity and caspase-mediated cleavage events can be formally demonstrated, then the administration of caspase inhibitors may, theoretically, serve to prevent or delay cell death in these patients [5].

Amyotrophic lateral sclerosis (ALS) is a fatal neurodegenerative disease that occurs in both sporadic and familial forms, some of which display mutations in the gene encoding the cytosolic $\mathrm{Cu} / \mathrm{Zn}$ superoxide dismutase gene [30, 31]. Transgenic mice have been generated which express human familial ALSassociated mutant superoxide dismutase, and these animals were shown to develop a motor neuron degenerative syndrome that closely resembles ALS. Interestingly, evidence for a functional role for caspase 1 and caspase 3 in presymptomatic and end-stage ALS mice has recently been demonstrated, and intracerebral administration of peptide-based caspase inhibitors was found to delay disease onset and mortality [32]. Finally, a promising cas- 
pase-based approach for the amelioration of nigral tissue transplant survival has recently been reported [33]. In this study, which may have important implications for the treatment of Parkinson's disease, caspase inhibitors were shown to reduce apoptosis in embryonic nigral cell suspensions and to improve the survival of dopaminergic neurons grafted to hemiparkinsonian rats, thereby improving functional recovery in these animals.

\section{Infectious Diseases}

Apoptosis of an infected cell may be viewed as a defense mechanism to prevent viral propagation, with the typical DNA fragmentation associated with apoptotic death thus serving to eliminate viral DNA sequences which have been incorporated into the cellular genome. Cytotoxic T cells also act to prevent viral spread by recognizing and killing virally infected cells by apoptosis. To circumvent these host defenses, many viruses have evolved specific strategies to inhibit apoptosis. For example, establishment of an effective adenoviral infection depends on the function of the E1B $19 \mathrm{~K}$ protein, a viral homologue of the antiapoptotic protein $\mathrm{Bcl}-2$ [34]. Another adenovirus protein, termed RID (receptor internalization and degradation), mediates internalization and subsequent lysosomal destruction of cell surface Fas, which may allow cells to resist Fasmediated death and thus promote the survival of the virus [35]. The inhibitor of apoptosis proteins (IAPs) found in baculoviruses can inhibit apoptosis in response to a wide variety of stimuli, and cellular IAPs have subsequently been identified that are believed to act as direct inhibitors of caspases. Numerous herpesviruses contain FLIPs (FLICE-inhibitory proteins) which possess sequences that interact with the Fas-associated adaptor protein, FADD [36]. This FLIP-FADD interaction is thought to inhibit signaling events induced upon ligation of Fas or the TNF receptor by their respective ligands. However, other viruses trigger apoptosis and/or cell lysis, perhaps for the purpose of facilitating viral release towards the end of the viral replicative cycle, and thereby succeed to promote viral infectivity and pathogenesis. An illustrative example is provided by recent studies in victims of Ebola virus infection, in which fatal outcome in patients was associated with massive intravascular apoptosis [37].

An increasing number of bacteria have been identified as triggers of apoptosis. For example, macrophages undergo apoptosis upon infection with Salmonella typhimurium, Shigella flexneri and Yersinia pseudotuberculosis. It has been speculated that the induction of macrophage death may be important to initiate infection, promote bacterial survival and escape from host immune responses. Recent data indicate that IpaB, a bacterial invasin of S. flexneri, induces apoptosis by binding directly to caspase 1 , a component of the macrophage apoptosis machinery [38]. Since caspase 1 is also a proinflammatory molecule, this binding may serve also to initiate inflammation. These findings raise the possibility of modulating the interaction between IpaB and caspase 1 as a target in both therapy and vaccine development. Moreover, it has been reported recently that the obligate intracellular bacterial pathogen Chlamydia trachomatis, a leading cause of many sexually transmitted diseases, possesses a novel antiapoptosis mechanism, namely the blockade of mitochondrial cytochrome $\mathrm{c}$ release and subsequent caspase activation [39]. Again, the elucidation of specific molecular targets of invading microbial agents may allow for more selective therapy of these diseases.

\section{Cancer}

Apoptosis and proliferation may be viewed as terms of the 'growth equation' and too 
much growth, as in the case of cancer development, may result from too little death as well as from too much proliferation. Moreover, if cancer arises due to mutations that lead to the dysregulation of normal apoptotic death, then antineoplastic therapies designed to circumvent these intrinsic defects and specifically trigger apoptosis should prove beneficial. Wyllie et al. [40] showed that cells which overexpress normal ras or myc proto-oncogenes induce tumors with high rates of both apoptosis and mitosis. However, cells that expressed the mutated, oncogenic form of the ras gene induced tumors with large numbers of mitotic cells, but few apoptotic cells. Depending on the availability of critical growth factors expression of c- $m y c$ itself does not induce apoptosis, but rather acts to sensitize cells to a wide range of distinct insults, such as serum or growth factor deprivation.

Vaux et al. [42] found that $b c l-2$, the translocation of which results in the progression of high-grade lymphomas, extends pre-B cell survival and that it cooperates with the myc oncogene to immortalize lymphocyte precursors. Additional studies revealed that Bcl-2 contributes to tumorigenesis by extending cell survival through direct inhibition of apoptosis [43]. Pathological elevations in the levels of one or more apoptosis-suppressing proteins of the Bcl-2 family have since been observed in several types of cancer. A decreased expression of Bax and Bak, proapoptotic members of the Bcl-2 family, has also been reported in several human cancers [44], and experiments with knockout animals have clearly demonstrated the ability of Bax to function as a tumor suppressor in vivo [45]. In addition to transcriptional regulation of $\mathrm{Bcl}-2$ family members, these molecules are also subject to posttranscriptional regulation, including phosphorylation and caspase-mediated cleavage, which may alter the sensitivity of cancer cells to therapy [11].

Apoptosis in Human Disease
Mutations in p53 are the most common chromosomal aberrations in human cancer. The role of apoptosis in malignant disease was underscored by the observation that $\mathrm{p} 53$ can induce apoptosis [46] and that p53-dependent apoptosis can serve as a critical regulator of tumorigenesis [47]. Activation of p53 by DNA-damaging agents is critical for eliminating cells with damaged genomic DNA and underlies the apoptotic response of human cancers treated with ionizing radiation and DNA-damaging drugs. When cells suffer DNA damage, the p53 protein accumulates due to posttranslational stabilization and blocks entry into the $\mathrm{S}$ phase. This transient delay at the $\mathrm{G}_{1}$ checkpoint in the cell cycle permits repair of damaged DNA prior to DNA replication. However, if DNA repair fails, p53 may trigger apoptosis. The expression of the $\mathrm{p} 21^{\text {waf- } 1}$ gene is directly induced by $\mathrm{p} 53$, and the waf- 1 protein has been implicated as an important effector of p53-mediated growth arrest [47]. p53 is also known to upregulate the expression of the bax gene, thereby altering the apoptotic 'rheostat' of the cell, i.e. the ratio of Bcl-2-toBax heterodimer formation [48]. Another candidate effector molecule is the cell surface receptor Fas, which is transcriptionally upregulated by $\mathrm{p} 53$ [49].

The observation that antineoplastic drugs may trigger apoptotic cell death was first reported by Searle et al. [50] yet has remained neglected until recently. Today, we know that a wide variety of chemotherapeutic agents induce apoptosis in tumor cell line in vitro. Conversely, resistance against chemotherapy may conceivably arise due to mutations in components of the apoptotic machinery. For instance, a number of recent reports have described the occurrence of Fas mutations in various malignancies. The Fas system may also play a role in the escape of tumor cells from immune surveillance. Hence, high constitutive Fas ligand expression has been demonstrated in different

Med Principles Pract 2000;9:151-163 
tumors, and it was suggested that such tumors may eliminate activated Fas-expressing lymphocytes by induction of apoptosis [51]. In addition, a novel Fas ligand decoy, DcR3 (decoy receptor 3) has recently been identified and suggested to enable tumor cells to evade surveillance by Fas-ligand-expressing cytotoxic lymphocytes [52]. In a sense, the tumor can be viewed as an immune-privileged site (discussed below). Indeed, the combination of Fas resistance, due either to Fas mutations or secretion of decoy receptors, coupled with the ability of tumor cells to express Fas ligand effectively enables a 'counter-attack' against the host immune system [51].

\section{Atherosclerosis and Stroke}

Atherosclerosis is characterized by thickening of the arterial intima, leading ultimately to thrombosis and organ infarction. Several cell types present in atherosclerotic lesions, including endothelial cells, smooth muscle cells and macrophages, are known to undergo apoptosis with varying outcome. For instance, apoptotic death of endothelial cells has been suggested to be an initial step in the development of atherosclerosis [53]. This hypothesis is supported by the observation that proatherosclerotic factors such as angiotensin II, oxidized low-density lipoprotein, reactive oxygen species and inflammatory cytokines all induce apoptosis in endothelial cells, whereas known protective factors such as estrogen and nitric oxide prevent apoptosis in these cells.

Loss of smooth muscle cells in vulnerable regions of an atherosclerotic plaque may jeopardize the integrity and stability of the plaque. Importantly, apoptosis of vascular smooth muscle cells has been demonstrated in atherosclerotic plaques [54]. We found that human aortic smooth muscle cells treated with 25hydroxycholesterol, an oxidation product of cholesterol, undergo apoptosis with activation of caspase 3 [55]. Apoptosis was potentiated by TNF and IFN- $\alpha$, suggesting that the effects of lipid oxidation products on cells in atherosclerotic lesions may be modulated by inflammatory cytokines present in the microenvironment. Furthermore, apoptosis was inhibited by the calcium channel blockers verapamil and nifedipine, thus serving to underscore the role of calcium as a second messenger in apoptosis signaling.

Neuronal death in stroke has previously been attributed to necrosis. However, recent studies have indicated that apoptosis may also contribute to neuronal demise in oxygen-deprived brains [26]. Moreover, several studies conducted in animal models have implicated caspase activation in neuronal cell death after stroke. Thus, systemic or intraventricular injection of a pan-caspase inhibitor, or a caspase-3-selective inhibitor, afforded neuroprotection in animal models of neonatal hypoxiaischemia [56] and focal ischemic infarction [57]. Caspase 3 activity was also shown to increase after experimental cerebral ischemia in rodents [58] and overexpression of X-chromosome-linked IAP prevented the activation of caspase 3 under these conditions, thus allowing neurons to survive after the ischemic insult [59]. Furthermore, a breach in the mitochondrial barrier and the release of mitochondrial caspase 9 was demonstrated in an animal model of cerebral ischemia, suggesting that mitochondrial events may be critical in postischemic neuronal damage [60]. Taken together, pharmacological suppression of apoptosis may prove particularly useful in acute disease processes such as stroke.

\section{Transplantation}

Graft rejection is a potential threat in all cases of tissue transplantation. However, there are certain immune-privileged sites in the body, such as the testis and the anterior chamber of the eye, where allogeneic or xenogeneic tissue grafts enjoy prolonged survival 
relative to other areas. While immune privilege was originally perceived as a passive process relying on physical barriers and isolation, recent data support the view of immune privilege as an active phenomenon. Specifically, a number of studies have indicated a role for Fas in maintaining the immune-privileged state and implicated the Fas system in both the regulation of physiological cell turnover and the protection of particular tissues against lymphocyte-mediated damage [61]. While some of these findings have been disputed by other investigators [62], they nevertheless provide a rationale for the manipulation of the local environment of a graft in a highly site- and immune-specific manner and could represent the beginning of a new era in transplantation immunology.

\section{Apoptosis as a Therapeutic Target}

While evidence for the involvement of dysregulation of apoptosis appears readily forthcoming in some cases (for instance, defective apoptosis in ALPS due to inherited Fas mutations), in other cases such evidence is only circumstantial and often based on crude methods of apoptosis detection in post mortem clinical specimens. The mere presence of DNA fragmentation in such specimens does not necessarily indicate apoptosis. Indeed, while caspase activation may be viewed as an integral feature of apoptotic cell death [63] even the detection of activated caspases, or cleavage of typical caspase substrates, may not suffice to label cells as 'apoptotic'. Therefore, great care should be taken to assess apoptosis by both morphological and biochemical criteria, and attempts should also be made to devise improved methods for the detection of apoptosis in vivo and in fixed pathological specimens.

The view that disease can result from the dysregulation of active cellular suicide mecha- nisms represents a novel paradigm in medicine. A critical question, however, is whether the labeling of dead cells as 'apoptotic' has added to our understanding of disease processes. Indeed, to establish that apoptosis occurs (or is lacking) in a particular disease does not mean to say that apoptosis defects are directly implicated in the pathogenesis of the condition and therefore a legitimate target for therapeutic intervention. For instance, it could be argued that the primary cause of $\mathrm{T}$ cell depletion in AIDS is not apoptosis per se but rather the inability of lymphopoiesis to replace the $\mathrm{CD} 4+\mathrm{T}$ cells lost prematurely because of the infection with HIV [64]. In this case, the enhanced rate of $\mathrm{T}$ cell apoptosis in cells obtained from HIV-infected persons may merely be reflective of chronic immune activation in these individuals, rather than being involved in the pathogenesis of the disease itself. Similarly, the findings that cells from patients with Niemann-Pick disease are resistant to radiation-induced apoptosis due to an inherited deficiency in acid sphingomyelinase activity [65] does not necessarily imply that these aberrations are associated with the development or progression of the disease. Therefore, the present challenge lies in the identification of those conditions in which dysregulation of apoptosis plays a causal role.

An important question is how to suppress apoptotic processes for therapeutic benefit, while maintaining an adequate degree of apoptosis in unaffected 'bystander' tissues. Indiscriminate inhibition of apoptosis could lead to the survival of genetically damaged cells which could pose a threat to the organism, whereas inappropriate promotion of apoptosis might lead to undesirable tissue degeneration. Nevertheless, one may envisage a number of apoptosis-regulating therapies (fig. 1), which could be utilized alone or in conjunction with conventional treatments, including gene therapy to induce enforced ag- 


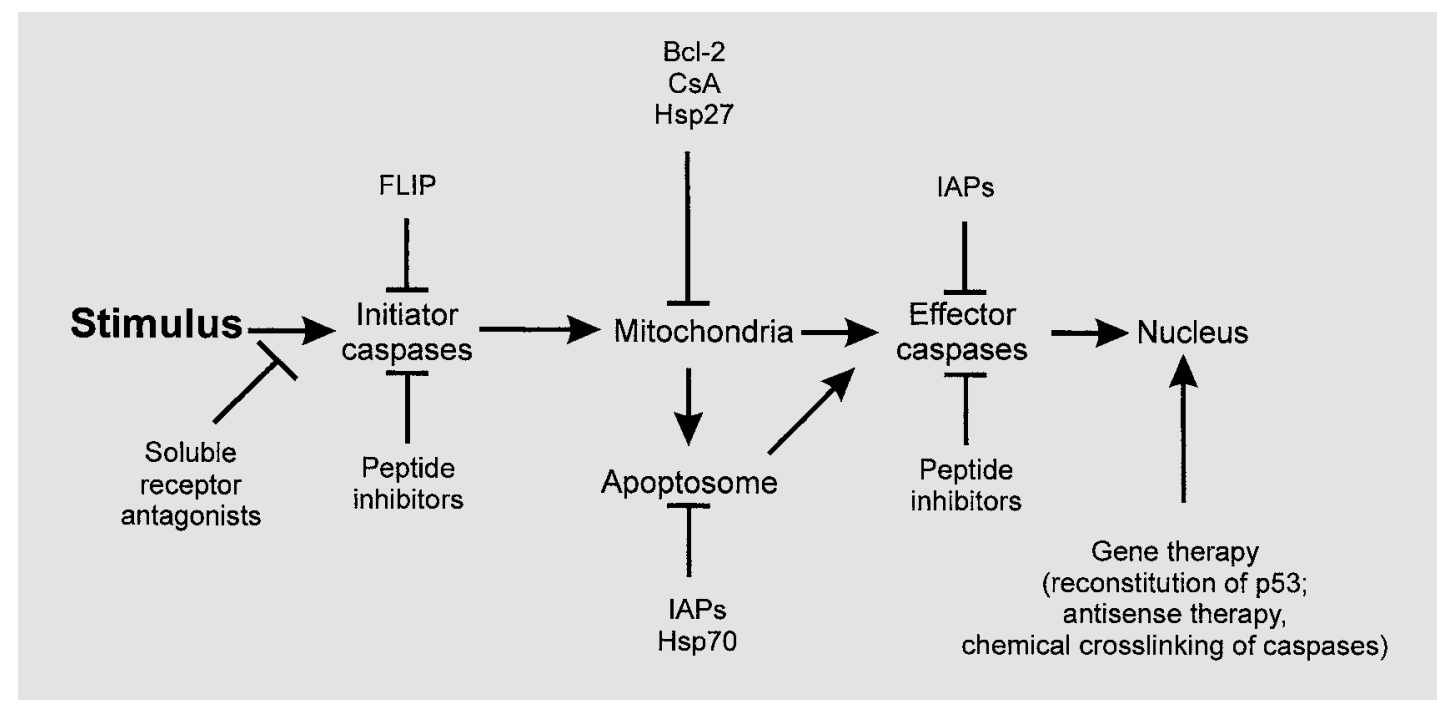

Fig. 1. Therapeutic strategies based on modulation of apoptosis. Numerous possibilities exist for interference with the core death pathway in mammalian cells, including inhibition of caspases upstream and downstream of the mitochondrion as well as direct perturbation of mitochondrial events. Signaling imparted by Fas and related death receptors at the plasma mem- brane constitutes another potential target to exploit for therapeutic gain. In addition, gene therapy targeted at caspases, members of the Bcl-2 and IAP families of proteins or the tumor suppressor gene, p53, has become an area of intensive investigation. CsA $=$ Cyclosporin A; FLIP = FLICE-inhibitory protein, $\mathrm{Hsp}=$ heat shock protein; IAP = Inhibitor of apoptosis protein. gregation and activation of caspases [66] or to reconstitute $\mathrm{p} 53$. The first clinical results of p53 reconstitution by gene therapy were reported by Roth et al. [67] who obtained tumor regression in 3 patients and tumor stabilization in 3 others out of 9 individuals with nonsmall-cell lung cancer with p53 mutations. Utilizing adenoviral vectors as an alternative delivery system, Bischoff et al. [68] were able to induce complete regression in $60 \%$ of implanted tumors in nude mice bearing human cervical carcinoma tumors. These authors used an E1B-55-kD-deficient adenovirus which is only able to replicate in and kill p53deficient cells, and these results therefore demonstrate the feasibility of using antitumor agents that kill only p53-deficient tumor cells, leaving normal cells unaffected. Future work should aim at the design of additional thera- pies targeted selectively against components of the apoptosis pathway in diseased tissues.

Another important question to consider is whether cells rescued from apoptosis are functional or whether they are simply 'undead' or anergic and, as a result of inadequate expression of recognition signals, not readily available for phagocytic clearance. In other words, rescuing a cell from death may not necessarily be equal to preserving its function. Indeed, it has recently been reported that in cells, which received signals via the Fas receptor in the presence of caspase inhibitors, the phenotype of death was merely switched from apoptosis to necrosis [69]. Similarly, in cells overexpressing Bcl-2, cell death induced by oxidized low-density lipoproteins shifted from apoptosis to necrosis [70]. It is also conceivable that apoptosis is so far down the sequence of irre- 
versible and irreparable changes in some diseases that blocking this process may not halt the progression of the disease itself. However, a recent study in the fruitfly indicates that suppression of apoptosis may, in fact, constitute a viable therapeutic approach. Davidson and Steller [71] employed a Drosophila model of retinitis pigmentosa and showed that the retinal degeneration due to mutations in either rhodopsin or a rhodopsin phosphatase gene occurred by apoptosis and could be blocked by caspase inhibitors with subsequent restoration of visual function in otherwise blind flies. Further proof of the principle that the suppression of apoptosis can result in improved cellular function was provided by Jilka et al. [72], who demonstrated that the increased bone mass caused by administration of parathyroid hor- mone is due, at least in part, to the salvage of osteoblasts by the prevention of apoptosis. Therefore, we remain confident that apoptosis-modulating strategies will be incorporated into our future therapeutic arsenal.

\section{Acknowledgements}

Presented in part as a Keynote Address by Professor Sten Orrenius at the Fifth Annual Poster Day of the Health Sciences Center, Kuwait University. This work was supported by the Swedish Medical Research Council, the Swedish Cancer Foundation, the Swedish Medical Society and the Research Foundation of Karolinska Institutet. The expert secretarial assistance of Mrs. Birgitta Blacker is also acknowledged. This paper is dedicated to the memory of Dr. Ahmed Fadeel, formerly at the Faculty of Science, Kuwait University, Kuwait.

\section{References}

1 Glücksmann A: Cell deaths in normal vertebrate ontogeny. Biol Rev Camb Philos Soc 1951;26:59-86.

2 Saunders JW: Death in embryonic systems. Science 1966;154:604612.

3 Kerr JFR, Wyllie AH, Currie AR: Apoptosis: A basic biological phenomenon with wide-ranging implications in tissue kinetics. Br J Cancer 1972;26:239-257.

4 Wyllie AH, Kerr JFR, Currie AR: Cell death: The significance of apoptosis. Int Rev Cytol 1980;68:251306.

5 Schilz JB, Weller M, Moskowitz MA: Caspases as treatment targets in stroke and neurodegenerative diseases. Ann Neurol 1999;45:421429.

6 Horvitz HR: Genetic control of programmed cell death in the nematode Caenorhabditis elegans. Cancer Res 1999;59(suppl):1701s-1706s.

7 Zou H, Henzel WJ, Liu X, Lutschg A, Wang X: Apaf-1, a human protein homologous to C. elegans CED4 , participates in cytochrome c-dependent activation of caspase-3. Cell 1997;90:405-413.
8 Vaux DL, Korsmeyer SJ: Cell death in development. Cell 1999;96:245254.

9 Earnshaw WC: A cellular poison cupboard. Nature 1999;397:387-389.

10 Nagata S: Apoptosis by death factor. Cell 1997;88:355-365.

11 Fadeel B, Zhivotovsky B, Orrenius S: All along the watchtower: On the regulation of apoptosis regulators. FASEB J 1999;13:1647-1657.

12 Ren Y, Savill J: Apoptosis: The importance of being eaten. Cell Death Diff 1998;5:563-568.

13 Savill J, Fadok VA, Henson PM, Haslett C: Phagocyte recognition of cells undergoing apoptosis. Immunol Today 1993;14:131-136.

14 Zhou T, Song L, Yang P, Wang Z, Liu D, Jope RS: Bisindolylmaleimide VIII facilitates Fas-mediated apoptosis and inhibits T cell-mediated autoimmune diseases. Nat Med 1999;5:42-48.

15 Rieux-Laucat F, Le Deist F, Hivroz C, Roberts IAG, Debatin K-M, Fischer A, de Villartay JP: Mutations in Fas associated with human lymphoproliferative syndrome and autoimmunity. Science 1997;268: 1347-1349.
16 Fisher GH, Rosenberg FJ, Straus SE, Dale JK, Middelton LA, Lin AY, Strober W, Lenardo MJ, Puck JM: Dominant interfering Fas gene mutations in pair apoptosis in a human autoimmune lymphoproliferative syndrome. Cell 1995;81:935946.

17 Wang J, Zheng L, Lobitom A, Chan FK-M, Dale J, Sneller M, Yao X, Puck JM, Straus SE, Lenardo MJ: Inherited human caspase 10 mutations underlie defective lymphocyte and dendritic cell apoptosis in autoimmune lymphoproliferative syndrome type II. Cell 1999;98:47-58.

18 Fadeel B, Orrenius S, Henter J-I: Induction of apoptosis and caspase activation in cells obtained from familial haemophagocytic lymphohistiocytosis patients. Br J Haematol 1999;106:406-415.

19 Stepp SE, Dufourcq-Lagelouse R, Le Deist F, Bhawan S, Certain S, Mathew PA, Henter J-I, Bennett M, Fischer A, de Saint Basile G, Kumar $\mathrm{V}$ : Perforin gene defects in familial hemophagocytic lymphohistiocytosis. Science 1999;286:1957-1959. 
20 Ohsako S, Elkon KB: Apoptosis in the effector phase of autoimmune diabetes, multiple sclerosis and thyroiditis. Cell Death Diff 1999;6:1321.

21 Itoh $\mathrm{N}$, Imagawa $\mathrm{A}$, Hanafusa $\mathrm{T}$, Waguri M, Yamamoto K, Iwahashi H, Moriwaki M, Nakajima H, Miyagawa J, Namba M, Makino S, Nagata S, Kono N, Matsuzawa Y: Requirement of Fas for the development of autoimmune diabetes in nonobese diabetic mice. J Exp Med 1997;186:613-618.

22 McConkey DJ, Orrenius S: The role of calcium in the regulation of apoptosis. Biochem Biophys Res Commun 1997;239:357-366.

23 Juntti-Berggren L, Larsson O, Rorsman P, Ämmälä C, Bokvist K, Wåhlander $\mathrm{K}$, Nicotera $\mathrm{P}$, Dypbukt $\mathrm{J}$, Orrenius S, Hallberg A, Berggren P$\mathrm{O}$ : Increased activity of L-type $\mathrm{Ca}^{2+}$ channels exposed to serum from patients with type I diabetes. Science 1993;261:86-90.

24 Srinivasan $\mathrm{S}$, Stevens MJ, Sheng $\mathrm{H}$, Hall KE, Wiley JW: Serum from patients with type 2 diabetes with neuropathy induces complement-independent, calcium-dependent apoptosis in cultured neuronal cells. J Clin Invest 1998;102:1454-1462.

25 Efanova IB, Zaitsev SV, Zhivotovsky B, Kohler M, Efendic S, Orrenius $\mathrm{S}$, Berggren P-O: Glucose and tolbutamide induce apoptosis in pancreatic $\beta$-cells. J Biol Chem 1998; 273:33501-33507.

26 Pettmann B, Henderson CE: Neuronal cell death. Neuron 1998;20: 633-647.

27 Springer JE, Azbill RD, Knapp PE: Activation of the caspase-3 apoptotic cascade in traumatic spinal cord injury. Nat Med 1999;5:943-946.

28 Los M, Wesselborg S, Schulze-Osthoff $\mathrm{K}$ : The role of caspases in development, immunity, and apoptotic signal transduction: Lessons from knockout mice. Immunity 1999;10: 629-639.

29 Goldberg YP, Nicholson DW, Rasper DM, Kalchman MA, Koide HB, Graham RK, Bromm M, KazemiEsfarjani P, Thornberry NA, Vaillancourt JP, Hayden MR: Cleavage of huntingtin by apopain, a proapoptotic cysteine protease, is modulated by the polyglutamine tract Nat Genet 1996;13:442-449.
30 Deng HX, Hentati A, Tainer JA Iqbal Z, Cayabyab A, Hung WY, Getzoff ED, $\mathrm{Hu}$ P, Herzfeldt B Roos RP, Warner C, Debg G, Soriano E, Smyth C, Parge HE, Ahmed A Roses AD, Hallewell RA, PericakVance MA, Siddique T: Amyotrophic lateral sclerosis and structura defects in $\mathrm{Cu}, \mathrm{Zn}$ superoxide dismutase. Science 1993;261:1047-1051.

31 Rosen DR, Siddique T, Patterson D, Figlewicz DA, Sapp P, Hentati A Donaldson D, Goto J, O'Regan JP, Deng HX, Rahmani Z, Krizus A, McKenna-Yasek D, Cayabyab A, Gaston SM, Berger R, Tanzi RE, Halperin JJ, Herzfeldt B, Van de Bergh R, Hung W-Y, Bird T, Deng G, Mulder DW, Smyth C, Laing NG, Soriano E, Pericak-Vance MA, Haines J, Rouleau GA, Gusella JS, Horvitz HR, Brown RH: Mutations in $\mathrm{Cu} / \mathrm{Zn}$ superoxide dismutase gene are associated with familial amyotrophic lateral sclerosis. Nature 1993;362:59-62.

32 Li M, Ona VO, Guégan C, Chen M, Jackson-Lewis V, Andrews LJ, Olszewski AJ, Stieg PE, Lee J-P, Przedborski S, Friedlander RM: Functional role of caspase-1 and caspase3 in an ALS transgenic mouse model. Science 2000;288:335-339.

33 Schierle GS, Hansson O, Leist M, Nicotera P, Widner H, Brundin P: Caspase inhibition reduces apoptosis and increases survival of nigral transplants. Nat Med 1999;5:97100.

34 Chiou SK, Tseng CC, Rao L, White E: Functional complementation of the adenovirus E1B 19-kilodalton protein with Bcl-2 in the inhibition of apoptosis in infected cells. J Virol 1994;68:6553-6566

35 Tollefson AE, Hermiston TW, Lichtenstein DL, Colle CF, Tripp RA, Dimitrov T, Toth K, Wells CE, Doherty PC, Wold WSM: Forced degradation of Fas inhibits apoptosis in adenovirus-infected cells. Nature 1998;392:726-730.

36 Thome M, Schneider P, Hofmann K, Fickenscher H, Meinl E, Neipel F, Mattmann C, Burns K, Bodmer J, Schroter M, Scaffidi C, Krammer PH, Peter ME, Tschopp J: Viral FLICE-inhibitory proteins (FLIPs) prevent apoptosis induced by death receptors. Nature 1997;386:517521.
37 Baize S, Leroy EM, Georges-Courbot M-C, Capron M, Lansoud-Soukate J, Debré P, Fisher-Hoch SP, McCormick JB, Georges AJ: Defective humoral responses and extensive intravascular apoptosis are associated with fatal outcome in Ebola virus-infected patients. Nat Med 1999;5:423-426.

38 Chen Y, Smith MR, Thirumalai K, Zychlinsky A: A bacterial invasin induces macrophage apoptosis by binding directly to ICE. EMBO J 1996;15:3853-3860.

39 Fan T, Lu H, Hu H, Shi L, McClarty GA, Nance DM, Greenberg AH, Zhong G: Inhibition of apoptosis in chlamydia-infected cells: Blockade of mitochondrial cytochrome c release and caspase activation. J Exp Med 1998;187:487-496.

40 Wyllie AH, Rose KA, Morris RG, Steel CM, Foster E, Spandidos DA: Rodent fibroblast tumors expressing human $m y c$ and ras genes: Growth, metastasis and endogenous oncogene expression. Br J Cancer 1987; 56:251-259.

41 Evan GI, Wyllie AH, Gilbert CS Littlewood TD, Land H, Brooks M, Waters CM, Penn LZ, Hancock DC: Induction of apoptosis in fibroblasts by c-myc protein. Cell 1992;69:119128.

42 Vaux DL, Cory S, Adams JM: Bcl-2 gene promotes haemopoietic cell survival and cooperates with c-myc to immortalize pre-B cells. Nature 1988;335:440-442.

43 Hockenberry D, Nunez G, Milliman C, Schreiber RD, Korsmeyer SJ: $\mathrm{Bcl}-2$ is an inner mitochondrial membrane protein that blocks programmed cell death. Nature 1990; 348:334-336.

44 Kelekar A, Thompson CB: Bcl-2family proteins: The role of the $\mathrm{BH} 3$ domain in apoptosis. Trends Cell Biol 1998;8:324-330.

45 Yin C, Knudson CM, Korsmeyer SJ, Van Dyke T: Bax suppresses tumorigenesis and stimulates apoptosis in vivo. Nature 1997;385:637640.

46 Yonish-Rouach E, Resnitzky D, Lotem J, Sachs L, Kimchi A, Oren M: Wild-type p53 induces apoptosis of myeloid leukemic cells that is inhibited by interleukin-6. Nature 1991; 352:345-347. 
47 Wiman KG: p53: Emergency brake and target for cancer therapy. Exp Cell Res 1997;237:14-18.

48 Miyashita T, Reed JC: Tumor suppressor p53 is a direct transcriptional activator of the human bax gene. Cell 1995;80:293-299.

49 Owen-Schaub LB, Zhang W, Cusack JC, Angelo LS, Santee SM, Fujiwara T, Roth JA, Deisseroth AB, Zhang W-W, Kruzel E, Radinsky R: Wild type human $\mathrm{p} 53$ and a temperaturesensitive mutant induce Fas/APO-1 expression. Mol Cell Biol 1995; 15: 3032-3040

50 Searle J, Lawson TA, Abbott PJ, Harmon B, Kerr JFR: An electronmicroscope study of the mode of cell death induced by cancer-chemotherapeutic agents in populations of proliferative normal and neoplastic cells. J Pathol 1975;116:129-138.

51 O'Connell J, Bennett MW, O'Sullivan GC, Collins JK, Shanahan F: The Fas counterattack: Cancer as a site of immune privilege. Immunol Today 1999;20:46-52.

52 Pitti RM, Marsters SA, Lawrence DA, Roy M, Kischkel FC, Dowd P, Huang A, Donahue CJ, Sherwood SW, Baldwin DT, Godowski PJ, Wood WI, Gurney AL, Hillan KJ, Cohen RL, Goddard AD, Botstein D, Ashkenazi A: Genomic amplification of a decoy receptor for Fas ligand in lung and colon cancer. $\mathrm{Na}$ ture 1998;396:699-703.

53 Dimmeler S, Hermann C, Zeiher AM: Apoptosis of endothelial cells. Contribution to the pathophysiology of atherosclerosis? Eur Cytokine Network 1998;9:697-698.

54 Bennett MR, Boyle JJ: Apoptosis of vascular smooth muscle cells in atherosclerosis. Atherosclerosis 1998; 138:3-9.

55 Ares MP, Porn-Ares MI, Thyberg J, Juntti-Berggren L, Berggren PO, Diczfalusy U, Kallin B, Bjorkhem I, Orrenius S, Nilsson $\mathrm{J}$ : $\mathrm{Ca}^{2+}$ channel blockers verapamil and nifedipine inhibit apoptosis induced by 25 -hydroxycholesterol in human aortic smooth muscle cells. J Lipid Res 1997;38:2049-2061.
56 Cheng Y, Deshmukh M, D'Costa A, Demaro JA, Gidday JM, Shah A, Sun Y, Jacquin MF, Johnson EM, Holtzman DM: Caspase inhibitor affords neuroprotection with delayed administration in a rat model of neonatal hypoxic-ischemic brain injury. J Clin Invest 1998;101: 1992-1999.

57 Endres M, Namura S, Shimizu-Sasamata M, Waeber C, Zhang L, Gomez-Isla T, Hyman BT, Moskowitz MA: Attenuation of delayed neuronal death after mild focal ischemia in mice by inhibition of the caspase family. J Cereb Blood Flow Metab 1998;18:238-247.

58 Namura S, Zhu J, Fink K, Endres M, Srinivasan A, Tomaselli KJ, Yuan J, Moskowitz MA: Activation and cleavage of caspase- 3 in apoptosis induced by experimental cerebral ischemia. J Neurosci 1998; 18:36593668.

59 Xu DG, Bureau Y, McIntyre DC, Nicholson DW, Liston P, Zhu YX, Fong WG, Crocker SJ, Korneluk RG, Robertson GS: Attenuation of ischemia-induced cellular and behavioral deficits by $\mathrm{X}$ chromosomelinked inhibitor of apoptosis protein overexpression in the rat hippocampus. J Neurosci 1999;19:50265033.

60 Krajewski S, Krajewska M, Ellerby LM, Welsh K, Xie Z, Deveraux QL, Salvesen GS, Bredesen GE, Rosenthal RE, Fiskum G, Reed JC: Release of caspase- 9 from mitochondria during neuronal apoptosis and cerebral ischemia. Proc Natl Acad Sci USA 1999;96:5752-5757.

61 Griffith TS, Ferguson TA: The role of FasL-induced apoptosis in immune privilege. Immunol Today 1997;18:240-244.

62 Yagita H, Seino K-I, Kayagaki N, Okumura K: CD95 ligand in graft rejection. Nature 1996;379:682683.

63 Samali A, Zhivotovsky B, Jones D, Nagata S, Orrenius S: Apoptosis: Cell death defined by caspase activation. Cell Death Diff 1999;6:459496.

64 Ameisen JC, Capron A: Cell dysfunction and depletion in AIDS: The programmed cell death hypothesis. Immunol Today 1991;12:102105.
65 Santana P, Pena LA, HaimovitzFriedman A, Martin S, Green D, McLoughlin M, Gordon-Cardo C, Schuchman EH, Fuks Z, Kolesnick R: Acid sphingomyelinase-deficient human lymphoblasts and mice are defective in radiation-induced apoptosis. Cell 1996;86:189-199.

66 MacCorkle RA, Freeman KW, Spencer DM: Synthetic activation of caspases: Artificial death switches. Proc Natl Acad Sci USA 1998;95: 3655-3660.

67 Roth JA, Nguyen D, Lawrence DD, Kemp BL, Carrasco $\mathrm{CH}$, Ferson DZ, Hong WK, Komaki R, Lee JJ, Nesbitt JC, Pisters KM, Putnam JB, Schea R, Shin DM, Walsh GL, Doloromente MM, Han CI, Martin FD, Yen N, Xu K, Stephens LC, McDonnel TJ, Mukhopadhyay T, Cai D: Retrovirus-mediated wildtype p53 gene transfer to tumors of patients with lung cancer. Nat Med 1996;2:985-991.

68 Bischoff JR, Kirn DH, Williams A, Heise C, Horn S, Muna M, Ng L, Nye JA, Sampson-Johannes A, Fattaey A, McCormick F: An adenovirus mutant that replicates selectively in p53-deficient human tumor cells. Science 1996;274:373-376.

69 Vercammen D, Brouckaert G, Denecker G, Van de Craen M, Declercq W, Fiers W, Vandenabeele P: Dual signaling of the Fas receptor: Initiation of both apoptotic and necrotic cell death pathways. J Exp Med 1998;188:919-930.

70 Meilhac O, Escargueil-Blanc I, Thiers JC, Salvayre R, Negre-Salvayre A: Bcl-2 alters the balance between apoptosis and necrosis, but does not prevent cell death induced by oxidized low density lipoproteins. FASEB J 1999;13:485-494.

71 Davidson FF, Steller H: Blocking apoptosis prevents blindness in Drosophila retinal degeneration mutants. Nature 1998;391:587-591.

72 Jilka RL, Weinstein RS, Bellido T, Roberson P, Parfitt AM, Manolagas SC: Increased bone marrow formation by prevention of osteoblast apoptosis with parathyroid hormone. J Clin Invest 1999;104:439446 . 